\title{
Colistimethate Sodium
}

National Cancer Institute

\section{Source}

National Cancer Institute. Colistimethate Sodium. NCI Thesaurus. Code C65349.

The sodium salt of colistimethate, a broad-spectrum polymyxin antibiotic against most aerobic Gram-negative bacteria except Proteus bacteria. Colistimethate sodium contains the pentasodium salt of the penta(methanesulfonic acid) derivative of colistin A as the major component and a small proportion of the petasodium salt of the pentamethanesulfonate derivative of colistin B. Colistins are cyclic polypeptides produced from Bacillus colistinus or B. polymyxa and function as a surfactant which penetrates into and disrupts the bacterial cell membrane, thereby resulting in bactericidal effect. 